\title{
SOIL SOLARIZATION IN THE CONTROL OF BEAN DISEASES CAUSED BY Sclerotium rolfsii
}

Vanessa Nataline Tomazeli ${ }^{1}$, Idalmir dos Santos ${ }^{2}$, Rafael Gustavo Ferreira Morales ${ }^{3}$, Alex Sandro Torre Figueiredo ${ }^{4}$

\footnotetext{
${ }^{1}$ Secretaria Estadual de Meio Ambiente do Rio Grande do Sul. E-mail: vanetomazeli@hotmail.com ${ }^{2}$ Universidade Tecnológica Federal do Paraná (UFTPR). E-mail: idalmir@uftpr.edu.br ${ }^{3}$ Empresa de Pesquisa Agropecuária e Extensão Rural de Santa Catarina (EPAGRI). E-mail: rafaelmorales@epagri.sc.gov.br

${ }^{4}$ Sakata Seed Sudamerica. E-mail: alexfigueiredo1987@yahoo.com.br
}

\begin{abstract}
This study aimed at assessing the effects of soil solarization on diseases caused by Sclerotium rolfsii in bean plants. Treatments consisted of solarization of a soil previously infested with $S$. rolfsii and a standard treatment (no solarization). A randomized block experimental design was adopted, with four replications. We assessed disease severity by measuring emergence, final stand, incidence, and severity of the disease. Soil microbial activity and number of viable sclerotia were evaluated after the second crop was grown in the first year of the experiment. In a two-year solarization period and under the temperatures achieved in this study it was not possible to control the diseases caused by the pathogen. However, the soil solarization decreases the incidence and severity of root collar rot caused by the fungus $S$. rolfsii in bean plants, as well as the pathogen's sclerotia viability.
\end{abstract}

Keywords: Phaseolus vulgaris L., sclerotia, temperature

\section{SOLARIZAÇÃO DO SOLO NO CONTROLE DAS DOENÇAS DO FEIJOEIRO CAUSADAS POR Sclerotium rolfsii}

\section{RESUMO}

O objetivo deste trabalho foi avaliar os efeitos da solarização do solo sobre as doenças causadas por Sclerotium rolfsii em feijoeiro. Os tratamentos utilizados foram a solarização do solo previamente infestado com S. rolfsii e um tratamento padrão (ausência da solarização do solo). O 
delineamento experimental foi de blocos ao acaso com quatro repetições. Avaliou-se a intensidade da doença pela emergência, estande final, incidência e severidade da doença. A atividade microbiana do solo e o número de escleródios viáveis foram avaliados após o segundo cultivo do primeiro ano de experimento. A solarização do solo reduziu a incidência e a severidade da podridão do colo causada pelo fungo $S$. rolfsii em feijoeiro, bem como a viabilidade de escleródios do patógeno, contudo, não é efetiva no controle total do patógeno. Em um período de solarização de dois anos e sob as temperaturas alcançadas neste estudo, não foi possível controlar as doenças causadas pelo patógeno. No entanto, a solarização do solo diminui a incidência e a severidade da podridão do colo da raiz causada pelo fungo $S$. rolfsii em plantas de feijão, bem como a viabilidade dos escleródios do patógeno.

Palavras-chave: Phaseolus vulgaris L., escleródios, temperatura

\section{INTRODUCTION}

Brazil is the world's largest producer of the common bean Phaseolus vulgaris L., with its production about 4.0 million tonnes/year. Bean is the basic protein food source in the nutrition of the Brazilian population. Sclerotium wilting or stem rot, caused by the fungus Sclerotium rolfsii, is among the most important bean diseases because it is hard to control. When infesting the soil, this pathogen causes great losses in productivity, which can reach $80 \%$ of production, mainly due to pre- and post-emergence damping-off (BIANCHINI et al. 1997; SOUZA \& BUENO, 2003); its sclerotia may survive in the soil for several years (BUENO et al. 2004). Control strategies such as seed chemical treatment, genetic resistance, and crop rotation help reduce the amount of inoculum, but have little effectiveness. This calls for additional tests to find alternatives that would present higher control effectiveness.

Physical control through solarization may be a viable option for soil disinfestation, including areas under protected cultivation, where soil use is quite intensive; such treatment may be effective at 30 to 45 days in the field and at 20 to 30 days in protected environments (PATRÍCIO et al. 2007). The most important effect of solarization consists in increased temperature provided by a transparent plastic film applied to the soil, causing the death of a significant part of the microorganisms present in that soil (GHINI et al. 2002). This technique provides positive results in the control of several soil-borne pathogens that are difficult to control, such as nematodes 
(BAPTISTA et al. 2006a) and sclerotia-forming fungi, such as Rhizoctonia solani (PATRÍCIO et al. 2007) and S. rolfsii (GAMLIEL \& STAPLETON, 1993; SOUZA \& BUENO, 2003). Control of these pathogens may occur due to soil heating (FERRAZ et al, 2003), since temperature is one of the main factors interfering with microorganism growth and survival (BAPTISTA et al. 2006b).

Sustainable production models prioritize reductions in the use of chemical products. However, in order to achieve this, all variables associated with potential control alternatives must be known. Therefore, this investigation aimed at evaluating the effect of soil solarization on diseases caused by S. rolfsii in bean (Phaseolus vulgaris L.) plants, as well as its relation with soil microbial activity and sclerotia survival.

\section{MATERIAL AND METHODS}

The study was carried out at Universidade Federal de Tecnologia do Paraná (UTFPR) Southwest Unit's experimental field, Pato Branco Campus, Brazil, at 26¹1'45.9"S latitude, $52^{\circ} 41 ' 29.7 " \mathrm{~W}$ longitude, and altitude of $700 \mathrm{~m}$.

The S. rolfsii isolate was obtained at UTFPR's Pato Branco plant pathology laboratory and was identified by optical microscopy. The pathogen was incubated for 10 days in Petri dishes containing PDA culture medium (potato-dextrose-agar, 39g/L) to obtain mycelial mass. The mycelium was then multiplied by placing 10 PDA disks ( $6 \mathrm{~mm}$ in diameter) containing the fungus at full development in 1-liter flasks, with substrates previously autoclaved for one hour during two consecutive days, containing: $100 \mathrm{~g}$ unhulled rice and $150 \mathrm{ml}$ distilled water. The unhulled rice substrate was incubated for 10 days at $25 \pm 2^{\circ} \mathrm{C}$. The soil was infested with $100 \mathrm{~g} / \mathrm{m}^{2}$ of that substrate 20 days before the treatments were applied.

Two treatments were evaluated: solarization and bare soil; a random block experimental design with four replicates was adopted. The experiment was repeated for two years, with two bean crops grown in the first year and one crop grown in the second year. A test crop was grown before the initial solarization to determine the presence and homogeneity of occurrence of the S. rolfsii fungus in the plots.

Solarized plots were covered with clear plastic (100 $\mu \mathrm{m}$ thickness), allowing 0.5-m borders on each side; the plastic borders were buried to hinder heat exchanges and moisture loss into the environment. Solarization was performed for two consecutive years, lasting 61 days in the first year (November and December) and 97 days in the second year (November, December, and 
January). It was decided to increase the solarization time from 61 to 97 days to intensify the effects of solarization in the second crop. Soil temperature was monitored daily at 0900 h, 1100 h, 1300 $\mathrm{h}$, and $1500 \mathrm{~h}$, at a 5-cm depth, with a soil temperature sensor (multimeter-thermocouple model Teste Electronico DT-830B). Approximately $100 \mathrm{~g}$ of soil were collected at six points from each plot to evaluate microbial activity. These evaluations were carried out only after the second crop was grown in the first year of the experiment, via $\mathrm{CO} 2$ release, according to the methodology described by Morales et al. (2007) adapted from Grisi (1978).

Seeding ( 80 bean seeds per plot, cultivar UTF-1, at 94\% germination power), was performed one week after the solarization plastic tarps were removed. Disease intensity was evaluated based on plant emergence, final stand, incidence and severity of root collar rot.

Emergence evaluations were performed by counting the number of emerged plants 12 days after seeding; final stand was based on total plants remaining after 24 days, at which point the plants were collected to evaluate the incidence and severity of root collar rot. Incidence was calculated as the percentage of infected plants with visible symptoms of the disease in relation to healthy plants. Severity was evaluated based on the percentage of injured tissue at the plant root collar, based on a diagrammatic scale for bean root rots (SCHOONHOVEN \& PASTORCORRALES, 1987). Identification and confirmation were performed under the optical microscope to ensure that the pathogen causing rot was indeed $S$. rolfsii.

After incidence and severity of the disease were evaluated, the plants were weighed and the results were divided by the final stand to obtain fresh matter mass per plant, in $\mathrm{g} / \mathrm{plant}$.

Another factor we evaluated was the number of sclerotia per plot, as well as their viability 15 days after the bean crop was harvested. To that effect, we collected dirt samples from six points at each plot ( $0-5 \mathrm{~cm}$ depth), totaling $500 \mathrm{~g}$. After homogenizing, a 50-g aliquot was taken from each sample; the aliquots were sifted through a five-sieve set with $4.75 \mathrm{~mm}, 2.36 \mathrm{~mm}, 1.00 \mathrm{~mm}$, $0.053 \mathrm{~mm}$, and $0.037 \mathrm{~mm}$ meshes, submitted to pressure under tap water. The three sieves with the smaller meshes were dipped into a white basin containing water, for sclerotia removal and counting. A sample consisting of ten randomly-selected sclerotia from each plot was utilized. The sclerotia were submitted to surface disinfestation in sodium hypochlorite at $2 \%$ for three minutes and plated in Petri dishes containing agar-water medium (2\%). Viability was evaluated after a 48hour period in a growth room at $25 \pm 2^{\circ} \mathrm{C}$, by counting germinated sclerotia. The 48 -hour period was 
determined in preliminary myceliogenic germination tests in which it was verified that viability was compromised when $100 \%$ germination would not occur within that period.

The data obtained were submitted to analysis of variance and the means were compared by Duncan's test at $5 \%$ probability. In the emergence, final stand, incidence, and severity analyses, the data were transformed to square root $(X+0.5)$.

\section{RESULTS AND DISCUSSIONS}

In both crops grown during the first year of the experiment, a reduction was observed in incidence and severity of root collar rot in plots submitted to solarization, as compared to plots without solarization. In the first crop grown, the mean incidence in non-solarized control plots was $67.30 \%$, with $21.52 \%$ severity, whereas under solarization incidence was reduced to $41.06 \%$, with $1.91 \%$ severity (Table 1 ).

Table 1. Effect of soil solarization on the incidence and severity of root collar rot caused by Sclerotium rolfsii, as well as on the emergence and final stand of bean plantlets (Phaseolus vulgaris L.) in crops grown after the plastic mulch was removed. Pato Branco, February 2005.

\begin{tabular}{llll}
\hline $1^{\text {st }}$ Crop $\left(1^{\text {st }}\right.$ Year) & & & \\
\hline Variable & No solarization & Solarized soil & CV $(\%)$ \\
\hline Incidence (\%) & $67.30 \mathrm{a}$ & $41.06 \mathrm{~b}$ & 1.37 \\
Severity (\%) & $21.52 \mathrm{a}$ & $1.91 \mathrm{~b}$ & 11.71 \\
Emergence (\%) & $76.41 \mathrm{a}$ & $78.13 \mathrm{a}$ & 17.72 \\
Final Stand (\%) & $65.78 \mathrm{a}$ & $71.56 \mathrm{a}$ & 20.89 \\
\hline $2^{\text {nd }}$ Crop (1 $1^{\text {st }}$ Year) & & & \\
\hline Incidence (\%) & $52.83 \mathrm{a}$ & $14.61 \mathrm{~b}$ & 3.54 \\
Severity (\%) & $16.84 \mathrm{a}$ & $1.57 \mathrm{~b}$ & 10.58 \\
Emergence (\%) & $81.56 \mathrm{a}$ & $81.48 \mathrm{a}$ & 21.56 \\
Final Stand (\%) & $79.77 \mathrm{a}$ & $81.41 \mathrm{a}$ & 25.33 \\
\hline $1^{\text {st }}$ Crop (2nd Year) & & & \\
\hline Incidence (\%) & $33.24 \mathrm{a}$ & $27.57 \mathrm{~b}$ & 2.58 \\
Severity (\%) & $6.89 \mathrm{a}$ & $4.01 \mathrm{~b}$ & 17.96 \\
Emergence (\%) & $73.52 \mathrm{a}$ & $78.44 \mathrm{a}$ & 12.45 \\
Final Stand (\%) & $72.61 \mathrm{a}$ & $76.79 \mathrm{a}$ & 13.69 \\
\hline
\end{tabular}

*Means followed by the same lower-case letter in the row do not differ significantly from each other by Duncan's test $(\mathrm{p} \leq 0.05)$.

In the second crop, incidence decreased from $52.83 \%$ to $14.61 \%$ and severity decreased from $16.84 \%$ to $1.57 \%$ between solarized and non-solarized plots, respectively. In the crop grown 
after the second solarization, although there was a reduction in intensity of the disease between treatments, such reduction was less expressive. Incidence decreased from $33.24 \%$ to $27.57 \%$, and severity decreased from $6.89 \%$ to $4.01 \%$ between non-solarized and solarized plots, respectively (Table 1).

Decreased incidence and severity with the use of solarization may be attributed to increased soil temperature, since, according to Katan \& Devay (1991), phytopathogenic microorganisms are the most affected by high temperatures, while their antagonists have greater resistance. Thus, as solarization promotes greater biological balance, it may both reduce pathogen populations, making them less aggressive to plants, or completely eliminate them from the environment. In this case, their reintroduction into the soil will be made harder by the antagonists (FERRAZ et al. 2003).

The maximum temperature observed in solarized seedbeds was $51.00^{\circ} \mathrm{C}$ in the $1^{\text {st }}$ year and $49.50^{\circ} \mathrm{C}$ in the $2^{\text {nd }}$ year, while the maximum observed in bare soil was $35.00^{\circ} \mathrm{C}$ in both crops grown. Just as observed by Patrício et al. (2007), the highest temperatures observed in the present work were recorded at 1500 hours (Figure 1). The mean temperature was similar in both years evaluated, with values of $46.8^{\circ} \mathrm{C}$ in the $1^{\text {st }}$ year in seedbeds submitted to solarization and $36.5^{\circ} \mathrm{C}$ in bare soil, i.e., a $10.3^{\circ} \mathrm{C}$ difference between them (Figure 1). In the second year the mean temperature in solarized plots was $43.15^{\circ} \mathrm{C}$, with $35.5^{\circ} \mathrm{C}$ in bare soil, a $7.65^{\circ} \mathrm{C}$ difference. It can be seen that in the second year temperatures were in general lower, which may have had an influence on the lower control efficiency provided by the method.

The increase in temperature-between 7 and $10^{\circ} \mathrm{C}$ - can be sufficient to control some soil plant pathogens. A $10.4^{\circ} \mathrm{C}$ difference at a $5 \mathrm{~cm}$ depth in solarized soils reduced the incidence of bacterial wilt caused by Ralstonia solanacearum (BAPTISTA et al. 2006b). Baptista et al. (2006a) observed a mean difference of $5.2^{\circ} \mathrm{C}$ between solarized and non-solarized soils at a $5 \mathrm{~cm}$ depth in the months of September and October; that temperature difference was sufficient to reduce the incidence of nematodes in tomato plant roots. 


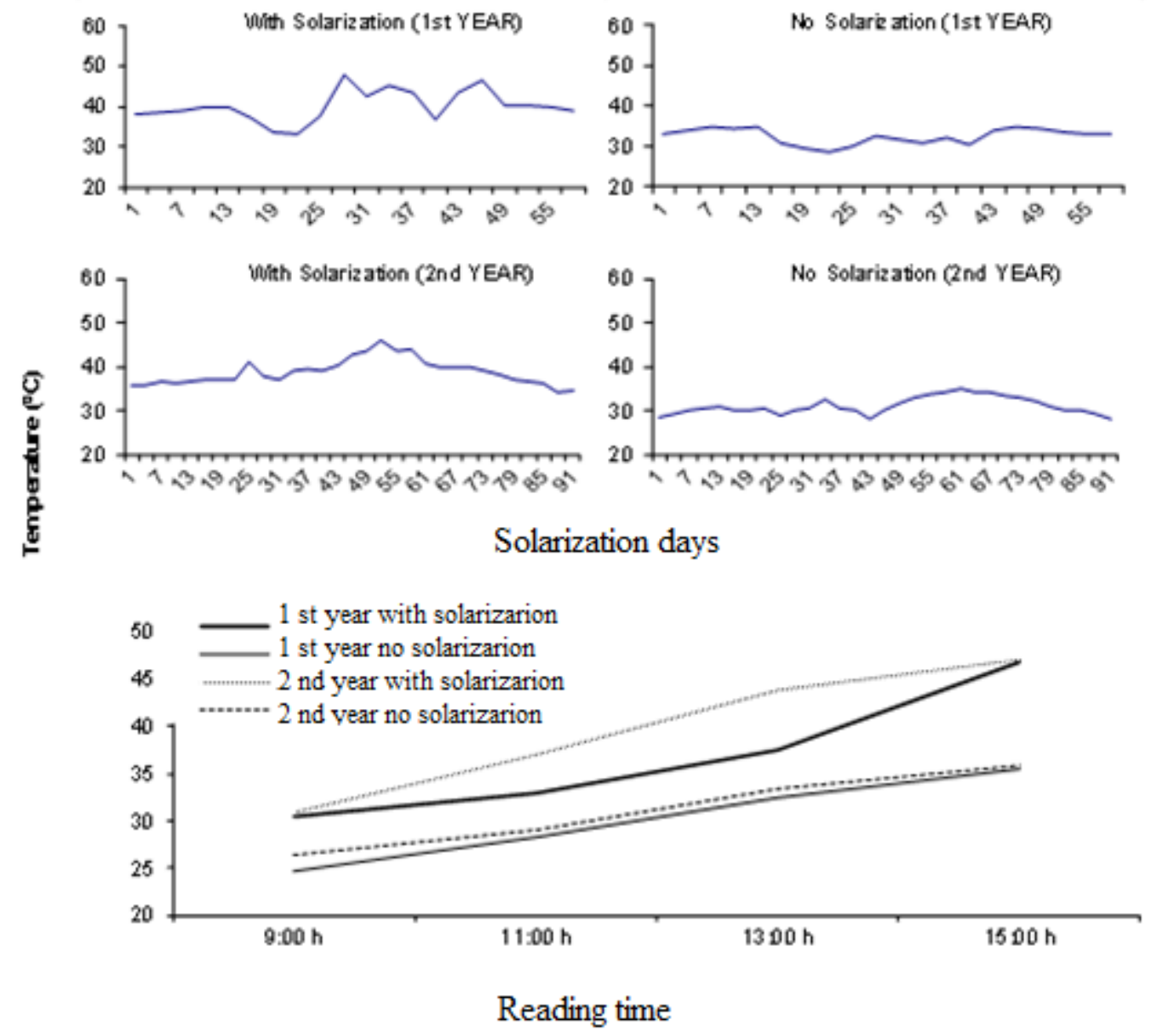

Figure 1. Mean daily temperature in soil under solarization and without solarization, during two years. Pato Branco, February 2005.

Plantlet emergence was not influenced by soil solarization in the three crops grown (Table 1). The lack of solarization effectiveness to control this disease at preemergence contradicts the results observed at postemergence; a more detailed investigation is required about this aspect. As to final stand and plant dry matter weight, the short period of time in which plants remained in the field (24 days after sowing) was decisive for the lack of damping off in plants with high severity. However, that 24-day period was enough for Morales et al. (2007) to evaluate the effect of incorporation of liquid swine manure on bean plantlet establishment in a soil infested with S. rolfsii. Tomazeli et al. (2011) also used the same period to evaluate the effect of organic residues in the control of bean plant diseases caused by $S$. rolfsii. 
There was a reduction in the number of viable $S$. rolfsii sclerotia in the soil submitted to solarization. The reduction in number of sclerotia may be attributed to fissures in their protective rings, due to increased temperature, which may have facilitated the attack of antagonistic microorganisms such as bacteria attracted by the pathogen exudates (FERRAZ et al. 2003). Elad et al. (1980) observed that soils treated with plastic mulch stimulated sclerotia exudation in $S$. rolfsii, increasing their colonization and destruction by bacteria. Soil microbial activity, as evaluated by $\mathrm{CO}_{2}$ release, did not decrease in solarized soils, which reinforces the idea that after the sclerotia had been damaged by high temperatures, antagonistic microorganisms present in the soil reduced sclerotia viability.

Table 2. Soil microbial activity and number of viable Sclerotium rolfsii sclerotia in soils with or without solarization, after growing the second crop in the first year of the experiment.

\begin{tabular}{llll}
\hline Variable & No solarization & Solarized soil & $\mathrm{CV}(\%)$ \\
\hline $\begin{array}{l}\text { Soil microbial activity } \\
\left(\mathrm{mg} \mathrm{CO} 2.100 \mathrm{~g} \mathrm{soil}^{-1}\right)\end{array}$ & $13.01 \mathrm{a}$ & $12.11 \mathrm{a}$ & 7.82 \\
$\mathrm{~N}^{\mathrm{o}}$ sclerotia $\left(\mathrm{n}^{\mathrm{0}} .50 \mathrm{~g} \mathrm{soil}^{-1}\right)$ & $25.73 \mathrm{a}$ & $10.19 \mathrm{~b}$ & 20.45
\end{tabular}

*Means followed by the same lower-case letter in the row do not differ significantly from each other by Duncan's test $(\mathrm{p} \leq 0.05)$.

\section{CONCLUSIONS}

In a two-year solarization period and under the temperatures achieved in this study it was not possible to control the diseases caused by the pathogen. However, the soil solarization decreases the incidence and severity of root collar rot caused by the fungus $S$. rolfsii in bean plants, as well as the pathogen's sclerotia viability.

\section{REFERENCES}

BAPTISTA, M. J.; SOUZA, R. B.; PEREIRA, W.; CARRIJO, A. O.; VIDAL, M. C.; CHARCHAR, J. M. 2006a. Solarização do solo e biofumigação no cultivo protegido de tomate. Horticultura Brasileira, Brasília, v.24, p. 47-52.

BAPTISTA, M. J.; SOUZA, R. B.; PEREIRA, W.; LOPES, C. A.; CARRIJO, O. A. 2006b. Efeito da solarização e biofumigação na incidência da murcha bacteriana em tomateiro no campo. Horticultura Brasileira, Brasília, v.24, p. 161-165.

BIANCHINI, A., MARINGONI, A. C.; CARNEIRO, S. M. T. P. G. 1997. Doenças do feijoeiro. In: KIMATI, H., AMORIN, L., BERGAMIN FILHO, A., CAMARGO, L. E. A.; RESENDE, J.A.M. (eds.) Manual de Fitopatologia, 3ed. Agronômica Ceres, São Paulo, pp.376-399. 
BUENO, C. J.; AMBRÓSIO, M. M. DE Q.; SOUZA, N. L. de; CEREZINI, P. C. 2004. Controle de Fusarium oxysporum f.sp. lycopersici raça 2, Macrophomina phaseolina e Sclerotium rolfsii em microcosmo simulando solarização com prévia incorporação de couve (Brassicae oleracea var. acephala L.). Summa Phytopathologica, Botucatu, v.30, p.356-363.

ELAD, Y.; KATAN, J; CHET, I. 1980. Physical, biological and chemical control integrated for soilborne diseases of potatoes. Phytopathology, Davis, v.70, p.418-422.

FERRAZ, L. C. L.; FILHO, A. B., AMORIM, L.; NASSER, L. C. B. 2003. Viabilidade de Sclerotinia sclerotiorum após a solarização do solo na presença de cobertura morta. Fitopatologia Brasileira, Brasília, v.28, p.17-26.

GAMLIEL, A., STAPLETON, J. J. 1993. Characterization of antifungal volatile compounds evolved from solarized soil amended with cabbage residues. Phytopathology, Davis, v.83, p.899-905.

GHINI, R., SHOENMAKER, I. A. S., BETTIOL, W. 2002. Solarização do solo, associada a incorporação de fontes de matéria orgânica no controle de Pythium spp. Pesquisa agropecuária brasiliera, Brasília, v.37, p. 1253-1261.

GRISI, B. M. 1978. Método químico de medição da respiração edáfica: alguns aspectos técnicos. Ciência e Cultura, Campinas, v.30, p.82-88.

KATAN, J.; DEVAY, J. E. 1991. Soil solarization: historical perspectives, principles, and uses. In: KATAN, J.; DEVAY, J. E. Boca Raton: CRC Press, p.103-129.

MORALES, R. G. F.; SANTOS, I.; DANNER, M. A. 2007. Efeito do chorume líquido de suínos na podridão do colo e tombamento de plântulas de feijoeiro causadas por Sclerotium rolfsii. Fitopatologia Brasileira, Brasília, v.32, p.429-433.

PATRÍCIO, F. R. A.; KIMATI, H.; TESSARIOLI NETO, J.; PETENATTI, A; BARROS, B. C. 2007. Solarização do solo em casa-de-vegetação e campo para o controle de Rhizoctonia solani AG-4. Summa Phytopathologica, Botucatu, v.33, p.245-251.

SCHOONHOVEN, A. V.; PASTOR-CORRALES, M. A. 1987. Standard System for the Evaluation of Bean Germplasm. CIAT, Cali. 56p.

SOUZA, N. L.; BUENO, C. J. 2003. Sobrevivência de clamidosporos de Fusarium oxysporum f. sp. Lycopersici raça 2 e escleródios de Sclerotium rolfsii em solo solarizado incorporado com matéria orgânica. Summa Phytopathologica, Botucatu, v.29, p. 153-160.

TOMAZELI, V.N.; SANTOS, I.; MORALES, R.G.F. 2011. Resíduos orgânicos para o controle das doenças do feijoeiro causadas por Sclerotium rolfsii. Ambiência, Guarapuava, v.7, n.1, p.65-74. 